\title{
PHILIA AS FRIENDSHIP IN NICHOLAS SPARKS' NOVEL THE LONGEST RIDE
}

\author{
Khafifah Aidhana Khairunnisa H., M. Manugeren \\ Universitas Islam Sumatera Utara \\ Medan, Indonesia \\ e-mail: khafifahaidhana@gmail.com
}

Received: 2021-10-02

Accepted: 2021-11-06

\begin{abstract}
This study is aimed at analyzing Philia as friendship in Nicholas Sparks' novel, The Longest Ride, published in 2013. The analysis is focused on the categories of Philia as friendship covering utility, happiness, and moral done by the major characters of the novel, namely Ira Levinson, Ruth, Luke Collins, Sophian Danko. The method used to analyze this study is a descriptive qualitative method. In this study, the researchers apply the theory of philia as friendship proposed by Aristotle. Philia is one type feeling of love in the Christian and Greek traditions based on friendly relations. Other types of love that are also in Christian theology are eros, agape and storage. The results show that the categories of Philia as friendship: utility, happiness and moral are reflected and done by the major characters. Utility is seen from Ira and Ruth with strong and healthy love relationship. Happiness is seen through Ira and Ruth who always feels happy when they see each other. Moral can be seen through the trust of Ira and Ruth who always share each and everything together.
\end{abstract}

Keywords: Philia, Friendship, Utility, Happiness and Moral

\section{Introduction}

The Longest Ride is a novel written by Nicholas Sparks. This novel is a romantic genre and has 398 pages. This novel was released in September 2013 and published by Grand Central Publishing in the United States. This novel has also been adapted into a film which was released two years after the release of the novel. In addition to the novel The Longest Ride, Nicholas Sparks released many bestselling novels such as The Notebook, Dear John, Massage in a Bottle, A Walk to Remember, The Last Long, The Lucky One, The Best of Me. The major characters of this novel are Sophia, Luke, Ruth and Ira. In this novel, Luke is a former rodeo champion who suffers an injury. During the healing process, he meets Sophia, a beautiful student who is studying in New York. The seeds of love emerge and an affair is formed between them. One day, there is a car accident, and they both help a man named Ira Levinson. Ira, who lives alone after separating from his wife, Ruth, keeps many letters in a wooden box, which Sophia reads. From the accident, Luke and Sophia learn a lot from Ira, especially love issues. As she and Luke fall in love, Sophia finds herself imagining a future far removed from her plans, a future that Luke has the power to recreate, if the secret Luke has shut up does not destroy it outright. The couple has a lot in common, and they accumulate experiences by years. However, their lives will be met with unexpected pain, given that 
Philia as Friendship in Nicholas Sparks' Novel The Longest Ride, Khafifah Aidhana Khairunnisa H., M. Manugeren

even the most difficult decisions can result in extraordinary journeys: transcend despair, death, to become farthest from the human heart. Philia is love that leads to friendship. Friendship is built on good relationships and is not only mutually beneficial, but also based on trust and dependability and, philia tends to be non-lustful.

\section{Literature Review}

\subsection{Literary Psychology}

Literature is the product of human thought and may be affected by the environment of the author, and may even include the author's lifestyle. Literary works are the mirror of human life. In other words, literary works are the reflections of social reality. The authors talk about the feelings and things they face in their social life (Sangidu, 2004: 2).

Literature is also tied to psychology. Psychology is the scientific study of mind and behavior. The word "psychology" comes from the Greek words "psyche," meaning life, and "logos," meaning explanation. According to Murphy, "psychology is the study of the response given by living things to their environment". Psychology is a science that studies open and closed behavior in humans, both as individuals and groups, in relation to the environment. Open behavior is behavior that is psychomotor which includes speaking, sitting, walking and so on, while closed behavior includes thinking, belief, feeling and so on (Syah, 2014).

Literary psychology with philia theory is closely related. The use of psychology in the study of literature involves intrinsic and extrinsic elements, especially characters and characterizations. Literature is considered as psychological phenomena that are studied through its characters. Literature is the discussion of life and society; everyone has love in his life; so, the discussion about love according to Philia can be studied with literary psychology (Wellek and Austin, 2012).

According to Wellek Warren (2012: 90), the term literary psychology has four possible meanings, namely: (1) study of the psychology of the author as a type or individual, (2) study of the creative process, (3) research on the types and psychological laws applied to literary works, and (4) research on readers. Literary psychology conducts literary research by treating literature as a psychological activity of authors and readers (Endaswara, 2018).). Literary psychology is an analysis of literary works using psychological considerations and relevance. This means that psychology should be used when analyzing literary works from the psychological perspective of the author, character and reader (Ratna, 2017: 350).

\subsection{Love}

Love is a universal human experience. It is viewed as a basic human emotion that may maninfest itself in a variety of forms and lead to a variety of cognitiveaffective responses and behaviors (Hatfield and Rapson, 2015). Another love taxonomy is proposed by social psychologist Robert Sternberg. In his triangular theory of love, Sternberg proposes that love is composed of three components: passion, commitment, and intimacy (Sternberg 2001: 119-135). The speed at which someone falls in love may be related to the target's physical attractiveness; people who fall in love quickly are more likely to do so if the target of their affection is physically attractive (Sangrador and Yela, 2000).

Love is one of the gifts that God gives to humans. Love can change anyone's life and love can also be interpreted as a feeling in humans due to its formation factors. 
Love can make a person's life happier and more special and love can also make people unhappy. Basically, no one can clearly define love because it does not have a pattern. That is why it is difficult to explain but can be felt. Love is not selfishness which aims to possess a whole person but only God who possesses human beings as a whole. Love always brings happiness to owning the world that looks so beautiful to those who feel it.

\subsection{Philia}

Philia is one type feeling of love in the Christian tradition and Greek tradition which is based on friendly relations. Other types of love that are also in Christian theology are eros, agape and storge. Philia is an ancient Greek language and there is no exact equivalent in English, simply people know that Philia is concerned with love. Philia is also reflected in various forms (Roman, 2016).

\subsubsection{Philia as Virtue}

The use of friendliness as the corresponding characteristic of the soul has never caused problems for researchers, because Aristotle's use of the word "Philia to refer to virtue is very contradictory. Aristotle provides a definition for this advantage, and he no longer names it by its similarities and differences with philia in another contextual meaning, friendship. For those who possess this kind of virtue, the people who correspond to this intermediate state, are what we call good friends.

\subsubsection{Philia as Friendship}

The content of philia as friendship can be carried out quickly and accurately, and this concept has always caused widespread controversy. The overall background of related research usually includes the range between two relative positions: all kinds of friendships are focused on the interests of others. Philia as friendship can be divided into three kinds, such as utility, happiness and moral.

\subsubsection{Utility}

The first kind of friendship is "for utility," where we seek help or benefit. This kind of friendship (1) "dissipates easily", that is to say, the required benefits are shortlived and relative to the "always changing" situation, and (2) does not require friends to "live together", which means, the communication itself is only temporary, provided that the participants are "useful to each other." The product appears to be alienated from the friend, that is to say, no matter what the object wants, the object may "not feel happy with each other." Both of these characteristics show the limitations of friendship at this level of interpersonal communication.

\subsubsection{Happiness}

The second kind of friendship is "for happiness". Unlike the first, this friendship seems to focus on the theme. For example, "These people do want to spend their days and lives together." However, it is as limited as temporary assistance. It only gives people the appearance of a shared life, because the passion for creating this situation is constantly changing. If we consider physical attraction to be a transient quality, then we find that the second friendship is the same as the first friendship. 
Philia as Friendship in Nicholas Sparks' Novel The Longest Ride, Khafifah Aidhana Khairunnisa H., M. Manugeren

\subsubsection{Moral}

The third kind of friendship is "moral", and its theme is "kind people", which also defines the characteristics of friendship. On the one hand, this friendship shares some common signs with the other two: utility and pleasure (these components not only exist, but are also necessary), on the other hand, its specific characteristics are also very different: (1) It is always constant, not accidental, because a person cannot make himself a moral person (in fact, the situation of a moral person produces stability, and "the wicked person is not one person, but many people, except himself, I am still a fickle person"; (2) There is no estrangement between the themes: "These desires are both good and beautiful with each other, which makes "moral". This brings us into the process of communication (including problems). A kind of moral egoism: philia or selflove), and here, kind guidance is revealed as a feature of the content.

\subsubsection{Philia as a Naturally Inherent Quality}

The supplementary term "friendship" allows us to define a conceptual residual, that is, content that cannot be reduced by virtue or specific forms of communication, which is a characteristic of active communication.

This type of irrationality refers to something more fundamental than virtue (state). "No matter what is in nature, nature does not have the ability to create excellence," our philosophers pervade the entire nature. Members of the same race feel this to each other.

In this case, it is completely easy to fall into the dilemma of "lexical and semantic mythology", the latter distinguishes the ancient love types in terminology, and begins to look for the difference between Philia and Eros, or conversely, excessive clarification "The Sorrow of Love" philia. "Actually, Aristotle's use of philia as a passion did not create any background to focus exclusively on this.

Philia is the love that leads to friendship. Friendship is built on good relationships, not only on mutual benefit, but also on the basis of trust and trust. Moreover, philia is often unflattering. Roman (2016) describes this ideas from Aristotle that friendship is divided into three types: kindness based on virtue, happiness based on pleasure and philia based on utility. The purest and best form of friendship is, of course, friendship based on virtue. This is kind friendship.

\section{Research Method}

The research method used is descriptive qualitative method. Qualitative research is a holistic approach that involves discovery. Qualitative research has also been described as an unfolding model that takes place in the natural environment, which enables researchers to develop a certain degree of detail through high participation in practical experience (Creswell, 2012). Qualitative method is also termed a scientific research that aims to understand a phenomenon in natural social contact with a deep interaction process between the researcher and the phenomena being studied (Haris, 2010).

The data collection procedures of this study are conducted by collecting the important data related to the subject matter of this study, searching for any theory related to the subject matter from books or websites and classifying the quotations based on the theories used to be analyzed. The next step is data analysis used to provide answers to research problems. The data obtained from these data are analysed based on 
the points of discussions. Words, phrases and sentences oriented to the concepts of Philia are taken, analyzed and elaborated to get the linear meanings.

\section{Discussion \\ 4.1 Utility}

Utility means goodness. Utility in the context of Philia as friendship means a relationship, especially a loving relationship, showing kindness to one another. Utility can be good communication, advice from a partner, and so on. Friendship as a utility can be seen through the quotation below.

I understood this intuitively, and for the next couple of months, neither of us pressed the other. We didn't speak of commitment, but we continued to see each other casually, perhaps two or three times a week. Sometimes I would take her to see a show or bring her to dinner, other times we would stroll downtown. There is an art gallery of which she'd grown particularly fond, and we visited regularly. Most of the artwork is unmemorable either in subject or in execution, but every now and then, Ruth would see something special in a painting that I could not (Sparks, 2013: 184).

The quotation above explains that friendship as a utility exists in this novel. It can be seen that the relationship between Ira and Ruth is a healthy love relationship. They do not press each other. Even though commitment looms over them, they stay relaxed and do not rush things. They are usual. Ruth gives Ira a lot of happiness, such as taking her to a show, having dinner, walking downtown. The kindness that Ira gives to Ruth is to let Ruth do her hobby, which is to see paintings in the gallery.

Friendship as a utility can be seen in the quotation.

Ruth gently revealed "we couldn't have children, careful not to place the blame entirely on me," though she could easily have done so. "I've always been thankful." (Sparks, 2013: 190).

The quotation above shows that friendship as utility exists in this novel. Utility characteristics are described through Ruth's behavior. Ira cannot have children. Ruth shows her kindness towards Ira by never mentioning or forcing hereditary issues. Even though Ruth could have been angry with Ira, she did not. Ira always feels grateful that Ruth always understands her.

Another friendship as a utility can be seen in the following lines.

"I close my eyes at her words. She is right, of course, right about all of

it. Ruth always did know me better than I knew myself." (Sparks, 2013: 142).

The quotation above shows that friendship as utility exists in this novel. The quotation also explains that the relationship between Ruth and Ira is very strong. They already know each other more than anything so that in their love relationship, Ruth really knows their personalities more deeply, and Ira knows very well that Ruth loves her very much, and for Ira, Ruth is everything, so in any decision and conditions, Ruth is very important. Ira believes that Ruth is always right in everything. 
Philia as Friendship in Nicholas Sparks' Novel The Longest Ride, Khafifah Aidhana Khairunnisa H., M. Manugeren

\subsection{Happiness}

In this discussion, happiness is intended as part of friendship that is forged in a relationship. Happiness not only seeks through physical attraction because it only temporary, but it seeks through living and spending days together. In The Longest Ride novel, friendship as happiness exists and this can be proven through the this quotation.

"That she saw something special in me made no sense at all, but I am bright enough to seize the opportunity. After that, we spent most of our free time together, although there isn't much left of it." (Sparks, 2013: 82).

Through the quotation above, it can be seen that Ruth always feels happy when she is near Ira, and vice versa. In establishing a relationship, they are always attached to complement their respective shortcomings, Ruth always considers their relationship very special even though for Ira it is impossible and unreasonable, but the feeling of regret is attached because of the memories that so tortured Ira when Ruth finds out that he dies earlier, so that only the beautiful memories they spend together remain in Ira's memory.

Friendship as happiness can also be seen through the followings.

"Then I want you to hear what I am saying to you, Ira," she says, her impatience barely in check. She leans forward. "I never once regretted that we married. You made me happy and you made me laugh, and if I could do it all over again, I would not hesitate. Look at our life, at the trips we took, the adventures we had. As your father used to say, we shared the longest ride together, this thing called life, and mine has been filled with joy because of you." (Sparks, 2013: 92-93).

It can be seen that the power of love between the two of them is a very unique thing, because for them loyalty is proven here, where for them their marriage is a happiness and the longest journey ever. They go through together, they live in joy and a sense of happiness that have grown together so making them grateful for each other and never hesitate in the slightest to live their marriage together because of their very deep gratitude for being destined to meet and live together.

Friendship as happiness can be seen in the quotation below.

"By then, Ruth and I were busy in the kitchen, preparing dinner. Over a simple meal of spaghetti with meat sauce, the four of us sat around the table as her father talked about their day, the conversation somehow segueing as it often did into a discussion about art." (Sparks, 2013: 226).

The quotation above explains that Ira is very well received by Ruth's family, starting from telling stories about what Ruth's parents dreaming about their happy marriage and also of Ruth herself, namely art so that conversations just flow like the conversations they often have at the dinner table, in fact not so but they are found by the same frequency so that the warmth of the conversation just blends in accidentally and unexpectedly. 


\subsection{Moral}

Moral means giving kindness and care to others. Moral can also be defined as the character of friendship. The state of the virtuous person produces stability. In this novel, the characters Ruth and Ira give moral messages to each other. Friendship as a moral can be seen through the quotation below.

"Trust people," he would tell me, "until they give you a reason not to.

And then never turn your back." (Sparks, 2013: 3).

The quotation above shows that trust is something precious. The quotation above explains that we can trust someone completely but one day it breaks our trust so we do not need to trust him anymore and even come back to him. The sentence "until they give you a reason not to", means until they give you a reason not to believe it. The word "give" here is not true, it means he gives a reason but it could be that he makes a mistake and accidentally we know it without his knowing. The point is never to turn to that person after he betrays our trust.

Friendship as moral also can be seen in the quotation below.

"I never told her about the cigarettes, for I know she would have disapproved. Ruth always hated their smell. It is lie of omission, but I long ago convinced myself that it is the right thing to do." (Sparks, 2013: 140).

The quotation above shows that everything about Ira is true. Ruth always knows the good and the bad. This love story really has a very different story from the others, it can be seen that Ruth is really detailed in everything about Ira's health so Ira never tells her about the cigarette because Ira knows that Ruth will be very angry and disappointed because Ruth knows she really hates the smell of the smell of the cigarettes and Ira always knows what Ruth does not like too, very unique.

Another friendship as moral also can be seen in the quotation below.

"Mostly I am preoccupied with the question of whether someone will ever fine me... In this world, after all, I've become more or less invisible." (Sparks, 2013: 227).

The quotation above shows a person's concern for himself. This quotation describes a person who is filled with questions about his worries about himself. Questions such as "Can a person find himself weak in this world? because after all the incidents that happen to him he feels increasingly weak and seems invisible in this world, asking again "Is there someone who is willing to stay by his side with his current condition?" This?". He needs someone who could look after and protect him. Worry and restlessness is what he feels, and the incident makes him feel even more helpless and worried that no one would be able to find him and accompany him.

What every last person failed to see is that it is not about money; it is about the memories they held (Sparks, 2013: 279).

The quotation above explains that in the end, Ruth and Ira realize that what is important in this world is actually the memories or the past that they have been through together, and not money. Money can still be found but memories cannot be found, because the truth is memories to remember and hold. 
Philia as Friendship in Nicholas Sparks' Novel The Longest Ride, Khafifah Aidhana Khairunnisa H., M. Manugeren

\section{Conclusion}

Through the analysis in Nicholas Sparks' novel The Longest Ride, the writers come to a conclusion that Philia as friendship can be seen from Ira and Ruth realationship. Philia as friendship can be defined as all kinds of friendship focused on the interest of others or only perfect friendships are in Philia. Then various forms come from Philia. The first is utility meaning kindness. Kindness in the context of Philia as friendship means relationship. Utility can also be defined as good communication, advice from other, and so on. In the story, utility can be seen from Ira and Ruth with strong and healthy relationship. It can also be seen through Ruth's behaviour towards Ira.

The second is happiness, intended as part of friendship that is forged in a relationship. Happiness is not only sought through physical attraction. Physical attraction is temporary. Happines is sought through living and spending days together. Happines in the story can be seen when Ruth and Ira always feels happy when they see each others. They share their dreams, worries and loyalty together

The third comes moral meaning giving kindnes and care to each others. Moral is one of friendship features. The state of the virtous person producer stability. In the story, moral can be seen through the trust that Ira and Ruth share things to each other. They think that trust is something precious in their relationship. Moral can also be found through Ira's behavious. Ira always shares everything to Ruth. Because of that, Ira knows what is good and bad for Ira. Then for the summing up, all forms of Philia, utility, happiness and moral are found in the novel

\section{References}

Creswell, John W. (2012). Research Desain (Pendekatan Kualitatif, Kuantitatif, and Mixed). Yogyakarta: Pustaka Pelajar.

Endaswara, Suwardi. (2018). Metodologi Penelitian Sastra. Yogyakarta: Widyatama.

Hatfield, E., \& Rapson, R. L. (2015). Love, sex, and intimacy: Their psychology, biology, and history. New York: HarperCollins

Haris, Hendriansyah (2010). Metodologi Penelitian Kualitatif. Jakarta: Salemba Humanika.

Ratna, Nyoman Kutha. (2017). Teori, Metode, Dan Teknik Penelitian Sastra. Denpasar: Pustaka Pelajar.

Roman S. Platonov. (2016). The Third Meaning of $\Phi_{l} \lambda \# \alpha$ (Philia) in Aristotle'sEthics, Russian Studies in Philosophy. Moscow: Rusian Lomonosov Moscow State University.

Sangidu. (2004). Metode Penelitian Sastra, Pendekatan Teori, Metode dan Kiat. Yogyakarta: UGM.

Sangrador, J.L., \& Yela, C. (2000). 'What is beautiful is 405 loved': Physical attractiveness in love relationships in 406 a representative sample. Social Behaviour and 407 Personality, 28, 207-218.

Sparks, Nicholas. (2013). The Longest Ride. New York: Grand Central Publishing

Sternberg, R.J. (2001). A triangular theory of love. 423 Psychological Review, 93, 119135. American Psychology Asociation, Inc.

Syah, Muhibbin. (2014). Psikologi Pendidikan dengan Pendekatan baru. Bandung: Remaja Rosdakarya.

Wellek, Rene and Austin Warren. (2012). Teori Kesusastraan. Jakarta: Gramedia. 